\title{
HARGA EMAS TERHADAP MINAT NASABAH BERINVESTASI MENGGUNAKAN PRODUK TABUNGAN EMAS
}

\author{
${ }^{1)}$ Mela Priantika, ${ }^{2}$ Sari Wulandari \\ ${ }^{3)}$ Mhd. Dani Habra \\ Universitas Muslim Nusantara Al Washliyah Medan \\ e-mail: sariwulandari@umnaw.ac.id
}

\begin{abstract}
Abstrak
Penelitian ini bertujuan untuk mengetahui pengaruh harga emas terhadap minat nasabah berinvestasi menggunakan produk tabungan emas pada PT. Pegadaian (Persero) Kantor Cabang Lubuk Pakam. Teknik analisis data yang digunakan yaitu deskriptif kuantitatif. Dengan sampel berjumlah 50 orang nasabah melalui metode purposive sampling. Hasil dari penelitian ini yaitu uji Koefisien Korelasi diperoleh nilai rxy sebesar 0,760, berarti harga emas berpengaruh positif dan kuat terhadap minat nasabah berinvestasi menggunakan produk tabungan emas. Untuk persamaan regresi didapatlah $Y=$ $12,155+0,759 \mathrm{X}$, dimana harga emas mempunyai pengaruh yang signifikan terhadap variabel minat nasabah berinvestasi menggunakan produk tabungan emas. Nilai koefisien determinan $\left(R^{2}\right)$ diperoleh sebesar 0,578 atau 57,8\% yang berarti bahwa harga emas berpengaruh terhadap minat nasabah berinvestasi menggunakan produk tabungan emas pada PT. Pegadaian (Persero) Kantor Cabang Lubuk Pakam. Mengetahui diterima atau tidaknya hipotesis dalam penelitian ini, digunakan uji $t$ (parsial) yang diperoleh dari harga emas $(x)$ memiliki nilai $t_{\text {hitung }} 8,105>t_{\text {tabel }} 2,011$. Dengan demikian Ha diterima karena $t_{\text {hitung }}>t_{\text {tabel }}$. Oleh karena itu, dapat disimpulkan bahwa harga emas secara parsial berpengaruh signifikan terhadap minat nasabah berinvestasi menggunakan produk tabungan emas.
\end{abstract}

Kata kunci: harga emas, minat berinvestasi

\begin{abstract}
This study aims to determine the effect of gold prices on customer interest in investing using gold savings products at PT. Pegadaian (Persero) Lubuk Pakam Branch Office. The data analysis technique used is descriptive quantitative, with sample of 50 customers through purposive sampling method. The results of this study, namely the Correlation Coefficient test, obtained rxy value of 0.760, which means that the price of gold has a positive and strong effect on customer interest in investing in gold savings products. For the regression equation, it is found that $Y=12.155+0.759 x$, where the price of gold has a significant influence on the variable of customer interest in investing in gold savings products. The value of the determinant coefficient $\left(R^{2}\right)$ is 0.578 or $57.8 \%$, which means that the price of gold has an effect on customers' interest in investing in gold savings products at PT. Pegadaian (Persero) Lubuk Pakam Branch Office. Knowing whether the hypothesis is accepted or not in this study, the t test (partial) is used which is obtained from the gold price $(x)$ which has a t-count value of 8.105>t-table 2.011. Thus $H a$ is accepted because $t$ count $>t$ table. Therefore, it can be concluded that the gold price partially has a significant effect on customers' interest in investing in gold savings products.
\end{abstract}

Keywords: gold price, investment interest

\section{PENDAHULUAN}

Kondisi ekonomi dan keuangan merupakan salah satu topik yang selalu berkembang dan menjadi perhatian masyarakat, baik masyarakat indonesia maupun masyarakat dunia. Perkembangan ekonomi tersebut akan senantiasa berubah seiring naiknya kebutuhan pokok, perubahan tersebut disebabkan oleh inflasi yang menurunkan daya beli masyarakat terhadap barang atau jasa akibat nilai tukar mata uang yang menurun. Peran investasi sangat penting untuk dapat mencegah penurunan lebih rendah lagi atau bahkan 
dapat meningkatkan pertumbuhan ekonomi.

Terkait dengan adanya kurs jual dan kurs beli pada harga emas yang menjadi pedoman jika mau menabung atau menjual emas dengan harga emas yang naik dan turun setiap harinya membuat nasabah harus selektif agar memperoleh keuntungan dalam berinvestasi emas. Dengan begitu pula ketika akan berinvestasi nasabah akan memilih investasi yang memiliki tingkat keuntungan yang tinggi dengan resiko yang rendah dengan demikian nasabah akan termotivasi menggunakan produk tabungan emas yang ditawarkan.

Investasi emas merupakan salah satu cara menabung yang sangat baik, karena nilai jual emas semakin lama semakin meningkat dan tingkat resiko sangat rendah sehingga nasabah dapat berinvestasi dengan aman tanpa memikirkan kerugian akibat tingkat resiko. Karena menabung emas dapat dilakukan pada seluruh cabang atau outlet pada PT. Pegadaian (Persero) di mana nasabah akan melakukan investasi. Nasabah akan termotivasi untuk melakukan investasi dengan tabungan emas, juga dipengaruhi oleh nilai jual emas yang tinggi serta kualitas logam mulia tersebut memiliki kualitas yang baik dimana kandungan emasnya 24 karat serta harga yang ditawarkan sangat terjangkau bagi nasabah dan untuk jangka panjang akan memiliki nilai jual yang akan terus meningkat.

Bentuk investasi emas paling diminati masyarakat karena nilainya tetap bahkan mengalami penaikan dari waktu ke waktu. Ada dua jenis investasi dengan emas, yakni dengan bentuk fisik dan online. Investasi fisik berarti seseorang memiliki bentuk fisik emas baik berupa perhiasan emas, koin emas dan emas batangan atau disebut juga logam mulia. Emas dalam bentuk fisik tersebut disimpan untuk jangka waktu tertentu. Investasi online seperti produk tabungan emas yang dapat digadai dan ditarik tunai jika nasabah membutuhkan dana karena tabungan emas bersifat liquid. Produk tabungan emas ini dapat diakumulasikan menjadi emas batangan atau logam mulia dan dapat dimiliki oleh nasabah dalam bentuk fisik dengan menabung di PT. Pegadaian (Persero) Kantor Cabang Lubuk Pakam.

Penelitian ini bertujuan untuk mengetahui apakah harga emas berpengaruh terhadap minat nasabah berinvestasi menggunakan produk tabungan emas pada PT. Pegadaian (Persero) Kantor Cabang Lubuk Pakam, dan untuk mengetahui seberapa besar harga emas berpengaruh terhadap minat nasabah berinvestasi menggunakan produk tabungan emas pada PT. Pegadaian (Persero) Kantor Cabang Lubuk Pakam.

Pendekatan dalam pemecahan masalah penelitian ini diantaranya dengan:

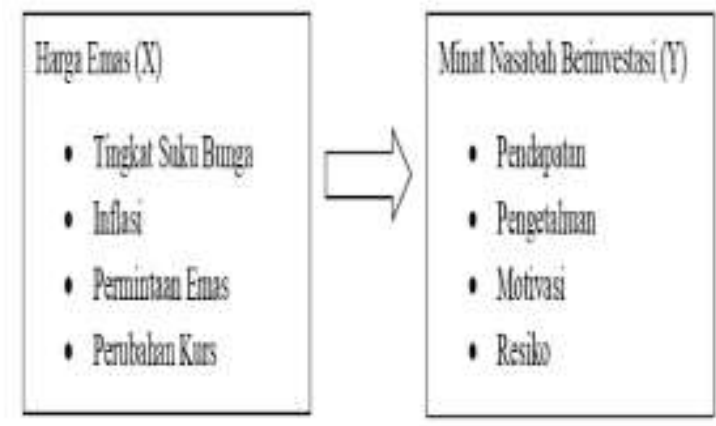

\section{METODE}

\subsection{Tehnik Pengumpulan Data}

Tehnik pengumpulan data dalam penelitian ini menggunakan 3 pendekatan diantaranya:
a. Observasi
b. Studi Dokumentasi
c. Angket (Kuesioner)

\subsection{Tehnik Analisis Data}

Tehnik analisis data yang digunakan dalam penelitian untuk menguji instrumen menggunakan uji validitas dan uji Reabilitas. metode analisis yang digunakan untuk membuktikan kebenarannya yaitu dengan metode deskriptif dan metode analisis kuantitatif. Uji selanjutnya berupa uji hipotesis dengan menggunakan regresi linier sederhana, Uji $t$, dan Uji determinan $\left(r^{2}\right)$. 


\section{HASIL DAN PEMBAHASAN}

\subsection{Uji Validitas}

Uji validitas dilakukan untuk mengukur apakah data yang telah didapat setelah penelitian merupakan data yang valid dengan alat ukur yang digunakan dalam meneliti, yaitu kuesioner. Jika instrument benar (valid) maka hasil pengukuran kemungkinan benar.

Tabel 3.1

Hasil Uji Validitas Haga Emas (X)

\begin{tabular}{|c|c|c|c|c|}
\hline No. & Pernyataan & $\mathbf{r}$ hitung & $\mathbf{r}$ tabel & Kesimpulan \\
\hline 1 & Pemyataan 1 & 0,754 & 0,361 & Vafid \\
\hline 2 & Penyataan 2 & 0,711 & 0,361 & Valid \\
\hline 3 & Penyataan 3 & 0,450 & 0,361 & Valid \\
\hline 4 & Penyyataan 4 & 0,560 & 0,361 & Valid \\
\hline 5 & Penyataan 5 & 0,659 & 0,361 & Valid \\
\hline 6 & Penyataan 6 & 0,490 & 0,361 & Valid \\
\hline 7 & Penyyataan 7 & 0,542 & 0,361 & Valid \\
\hline 8 & Pemyataan 8 & 0,387 & 0,361 & Valid \\
\hline 9 & Penyatann 9 & 0,489 & 0,361 & Valid \\
\hline 10 & Penyyataan 10 & 0,436 & 0,361 & Valid \\
\hline
\end{tabular}

Simber : data diolah peneliti

Hasil uji validitas variabel Harga Emas pada tabel 3.1 di atas menunjukkan 10 pernyataan yang mewakili variabel Harga Emas adalah valid karena memiliki nilai $r_{\text {hitung }}>r_{\text {tabel }}(0,361)$.

Tabel 3.2

Hasil Uji Validitas Minat Nasabah Berinvestasi ( $($ )

\begin{tabular}{|c|c|c|c|c|}
\hline No. & Pernyataan & $r$ hitung & $r$ tahel & Kesimpulan \\
\hline 1 & Pernyataan 1 & 0,596 & 0,361 & Valid \\
\hline 2 & Permyataan 2 & 0,611 & 0,361 & Valid \\
\hline 3 & Pernyataan 3 & 0.639 & 0,361 & Volid \\
\hline 4 & Permyataan 4 & 0,623 & 0,361 & Valid \\
\hline 5 & Peruyataan 5 & 0,478 & 0,361 & Volid \\
\hline 6 & Peruyataan 6 & 0,510 & 0,361 & Valid \\
\hline 7 & Peruystaan 7 & 0,684 & 0,361 & Valid \\
\hline 8 & Pernyataan 8 & 0,644 & 0,361 & Valid \\
\hline 9 & Pernyataan 9 & 0,587 & 0,361 & Valid \\
\hline 10 & Pernyatain 10 & 0.522 & 0.361 & Valid \\
\hline
\end{tabular}

Hasil uji validitas variabel Minat Berinvestasi pada tabel 3.2 di atas menunjukkan 10 pernyataan yang mewakili variabel Minat Berinvestasi adalah valid karena nilai $r_{\text {hitung }}>r_{\text {tabel }}(0,361)$.

\subsection{Uji Reabilitas}

Uji Realibilitas merupakan pengujian untuk melihat apakah instrumen penelitian merupakan instrumen yang handal dan dapat dipercaya. Jika variabel penelitian menggunakan instrumen yang handal dan dapat dipercaya maka hasil penelitian juga dapat memiliki tingkat kepercayaan yang tinggi.

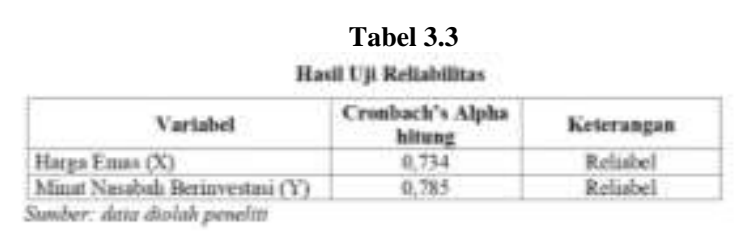

Berdasarkan tabel 3.3 hasil uji reliabilitas di atas, nilai cronbach alpha untuk variabel Harga Emas adalah $(0,734)$ dan variabel Minat Nasabah Berinvestasi adalah $(0,785)$. Hal ini berarti bahwa pernyataan untuk seluruh variabel Harga Emas dan Minat Nasabah Berinvestasi dikatakan reliabel atau terpercaya, karena tingkat instrumen penelitian sudah mendekati $1(\geq$ dari 0,60$)$.

\subsection{Uji Analisis Regresi Linier Sederhana}

Untuk mengetahui pengaruh Harga Emas Terhadap Minat Berivestasi Menggunakan Produk Tabungan Emas di PT. Pegadaian (Persero) Cabang Lubuk Pakam, maka digunakan analisis regresi linier sederhana, Hasil yang diperoleh dengan menggunakan program SPSS versi 22,0 dapat dilihat pada tabel 3.4 berikut:

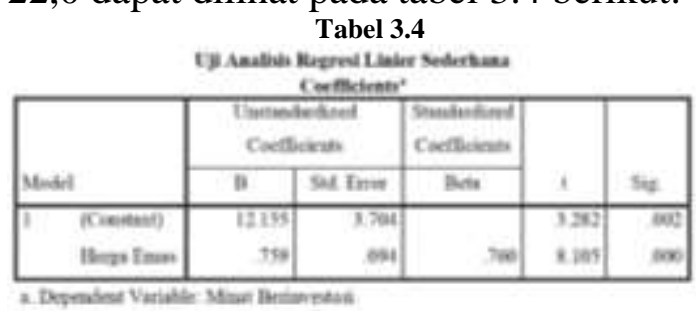

Pada tabel 3.4 menunjukkan bahwa perhitungan diperoleh nilai konstanta (a) 12,155 dan (b) 0,759 sehingga diperoleh persamaan regresi linier sederhana

$\mathbf{Y}=\mathbf{1 2 , 1 5 5}+\mathbf{0 , 7 5 9 X}$, dimana Harga Emas mempunyai pengaruh yang signifikan terhadap variabel Minat Nasabah Berinvestasi. Hal ini dapat dilihat dari keterangan sebagai berikut:
1. Konstanta
(a) sebesar
12,155 menunjukkan bahwa tanpa adanya variabel Harga Emas besar nilai Minat 
Nasabah Berinvestasi Menggunakan Produk Tabungan Emas Pada PT. Pengadaian (Persero) Kantor Cabang Lubuk Pakam adalah sebesar 12,155.

2. Harga Emas (X) sebesar 0,759 menunjukkan bahwa variabel Harga Emas cukup berpengaruh positif dan signifikan terhadap Minat Nasabah Berinvestasi Menggunakan Produk Tabungan Emas, artinya setiap terjadi peningkatan variabel Harga Emas, maka akan berpengaruh positif terhadap peningkatan Minat Nasabah Berinvestasi Menggunakan Produk Tabungan Emas.

\subsection{Uji t (Parsial)}

Uji t dilakukan untuk membuktikan hipotesis dengan membandingkan $t_{\text {hitung }}$ dengan $t_{\text {tabel }}$. Apabila $t_{\text {hitung }}>t_{\text {tabel }}$ dan nilai signifikansi $<\alpha=0,05$ maka dikatakan pengaruhnya signifikan, dan apabila $t_{\text {hitung }}$ $<\mathrm{t}_{\text {tabel }}$ nilai signifikansi $>\alpha=0,05$ maka dikatakan pengaruhnya tidak signifikan. Tabel 3.5 eir

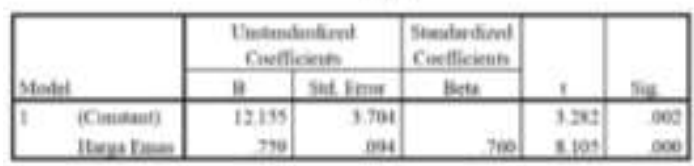

Berdasarkan pada tabel 3.5 nilai $\mathrm{t}_{\text {tabel }}$ untuk probabilitas 0,05 uji signifikansi dua arah pada derajat bebas $=50$ adalah sebesar 2,01063. Dengan demikian hasil dari Uji $t$ dapat dijelaskan sebagai berikut: Hasil perhitungan uji $t$ secara parsial diperoleh nilai $t_{\text {hitung }}$ Harga Emas sebesar 8,105 dengan nilai signifikan sebesar 0,000. Nilai $\mathrm{t}_{\text {hitung }}>\mathrm{t}_{\text {tabel }}$ atau 8,105 $>2,01063$, maka $H_{a}$ diterima artinya Harga Emas (X) secara parsial berpengaruh positif dan signifikan terhadap Minat Nasabah Berinvestasi Menggunakan Produk Tabungan Emas (Y) pada PT. Pegadaian (Persero) Kantor Cabang Lubuk Pakam.

\subsection{Uji Koefisien Determinan $\left(\mathbf{R}^{2}\right)$}

Koefisien determinasi $\left(\mathrm{R}^{2}\right)$ digunakan untuk mengetahui seberapa besar kontribusi variabel bebas dalam menjelaskan variasi variabel terikat. Hasil perhitungan Koefisien Determinasi penelitian ini dapat dilihat pada table 3.6 berikut ini:

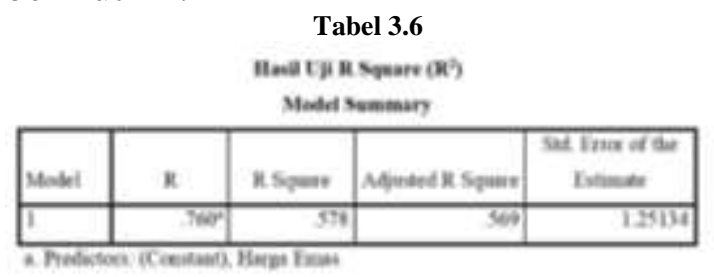

Berdasarkan Tabel 3.6 diperoleh nilai $R$ Square $\left(\mathrm{R}^{2}\right)$ sebesar 0,578. Dengan kata lain ini menunjukan bahwa sebesar presentase variasi variabel Minat Nasabah Berinvestasi yang bisa dijelaskan oleh variasi variabel bebas yaitu Harga Emas sebesar 57,8 \% sedangkan sisanya sebesar $42,2 \%$ dijelaskan oleh variabel-variabel lain diluar variabel penelitian ini.

\subsection{Pembahasan}

Berdasarkan analisis data penelitian diketahui bahwa sebagian besar responden menyatakan bahwa Harga Emas termasuk dalam kategori baik. Harga Emas ini memberikan hasil yang positif dan signifikan terhadap Minat Nasabah Berinvestasi Menggunakan Produk Tabungan Emas, artinya jika Harga Emas semakin baik maka akan berpengaruh terhadap meningkatnya Minat Nasabah Berinvestasi Menggunakan Produk Tabungan Emas. Hal ini didukung oleh koefisien regresi sebesar 0,759 serta uji signifikasi persial (uji t) yang menghasilkan nilai $\mathrm{t}$ hitung sebesar 0,8105 dengan signifikasi 0,000 $(p<0,05)$. Harga Emas yang baik berpengaruh positif terhadap Minat Nasabah Berinvestasi Menggunakan Produk Tabungan Emas pada PT. Pegadaian (Persero) Kantor Cabang Lubuk Pakam dengan koefisien determinan $\left(\mathrm{R}^{2}\right)$ diperoleh sebesar 0,578 atau $57,8 \%$ sedangkan sisanya sebesar 42,2 \% dijelaskan oleh faktor lain diluar analisa variabel dalam penelitian ini. Selain itu tanda positif pada angka 0,578 menunjukan adanya arah yang sama dari kedua variabel tersebut, artinya semakin baik Harga Emas maka Minat Nasabah Berinvestasi 
Menggunakan Produk Tabungan Emas akan semakin meningkat.

\section{KESIMPULAN}

Berdasarkan berbagai pengujian dan analisis data, dari penelitian ini dapat diperoleh beberapa kesimpulan mengenai Pengaruh Harga Emas Terhadap Minat Nasabah Berinvestasi Menggunakan Produk Tabungan Emas Pada PT. Pegadaian (Persero) Kantor Cabang Lubuk Pakam:

1. Berdasarkan Hasil Koefisien Korelasi diperoleh nilai rxy $=0,760$, berarti Pengaruh Harga Emas Terhadap Minat Nasabah Berinvestasi Menggunakan Produk Tabungan Emas adalah positif dan kuat.

2. Berdasarkan uji regresi linier sederhana, maka diperoleh persamaan nilai konstanta sebesar 12,155 dan nilai b 0,759, sehingga diperoleh persamaan regresi linier sederhana $Y=12,155+$ 0,759, dimana Harga Emas mempunyai pengaruh signifikan terhadap Minat Nasabah Berinvestasi Menggunakan Produk Tabungan Emas.

3. Berdasarkan uji t di ketahui bahwa hasil yang diperoleh dari Harga Emas (X) memiliki nilai $t_{\text {hitung }} 8,105>t_{\text {tabel }}$ 2,011, maka Ha diterima karena $t_{\text {hitung }}>$ $t_{\text {tabel }}$ sehingga Harga Emas secara parsial berpengaruh terhadap Minat Nasabah Berinvestasi Menggunakan Produk Tabungan Emas pada PT. Pegadaian (Persero) Kantor Cabang Lubuk Pakam.

4. Nilai Koefisien determinan $\left(\mathrm{R}^{2}\right)$ diperoleh sebesar 0,578 atau 57,8\%, yang berarti baha variabel Harga Emas berpengaruh terhadap Minat Nasabah Berinvestasi Menggunakan Produk
Tabungan Emas pada PT. Pegadaian (Persero) Kantor Cabang Lubuk Pakam.

\section{DAFTAR PUSTAKA}

Arikunto, Suharsimi. (2010). Manajemen Penelitian. Rineka Cipta. Jakarta.

Cristy, Laura. (2014). Analisis Faktorfaktor Yang Mempengaruhi Harga Emas di Indonesia. Institut Pertanian Bogor.

Ghozali, Imam. (2012). Aplikasi Analisis Multivariate dengan Program IBM SPSS 22. Badan Penerbit Universitas Diponegoro. Semarang.

Kotler, Philip dan Kevin Lane Keller. (2013). Manajemen Pemasaran Jilid Kedua. Indeks. Jakarta.

Malik, Ahmad Dahlan. (2017). Analisa Faktor-faktor Yang Mempengaruhi Minat Masyarakat Berinvestasi di Pasar Modal Syariah Melalui Bursa Galeri Investasi UISI. Universitas Internasional Semen Indonesia.

Priansa, Donni Juni. (2017). Perilaku Konsumen. Alfabeta. Bandung.

Sodik, Muhammad. (2016). Pengaruh Fluktuasi Harga Emas Terhadap Minat Bertransaksi Nasabah Pegadaian Syariah (Studi Kasus Pada Pegadaian Syariah Raden Intan Bandar Lampung). Universitas Islam Negeri Raden Intan Lampung.

Sugiyono. (2010). Metodologi Penelitian (Pendekatan Kuantitatif, Kualitatif, dan $R \& D)$. Alfabeta. Bandung.

Suryomurti, Wiku. (2011). Investasi Syariah. Qultum Media. Jakarta.

http://digital.pegadaian.co.id https://sahabatpegadaian.com https://id.m.wikipedia.org 